\title{
Substitution of soybean meal for urea in diets based on deferred buffelgrass hay for feedlot sheep
}

\author{
Gildenia Araújo Pereira ${ }^{1 *}$, Juliana Silva de Oliveira1, Edson Mauro Santos ${ }^{1}$, Gleidson Giordano \\ Pinto de Carvalho², Gherman Garcia Leal de Araújo ${ }^{3}$, Wandrick Hauss de Sousa ${ }^{4}$, Sansão de \\ Paula Homem Neto ${ }^{5}$, Felipe Queiroga Cartaxo ${ }^{6}$
}

\author{
${ }^{1}$ Universidade Federal da Paraíba, Departamento de Zootecnia, Areia, PB, Brasil. \\ 2 Universidade Federal da Bahia, Departamento de Zootecnia, Salvador, BA, Brasil. \\ ${ }^{3}$ Empresa Brasileira de Pesquisa Agropecuária, Centro de Pesquisa Agropecuária do Trópico Semiárido, Petrolina, PE, Brasil. \\ ${ }^{4}$ Empresa Estadual de Pesquisa Agropecuária da Paraíba, João Pessoa, PB, Brasil. \\ ${ }^{5}$ Universidade Estadual do Sudoeste da Bahia, Programa de Pós-graduação em Zootecnia, Itapetinga, BA, Brasil. \\ ${ }^{6}$ Universidade Estadual da Paraíba, Departamento de Agrárias e Exatas, Catolé do Rocha, PB, Brasil.
}

\begin{abstract}
The objective of this study was to evaluate the effect of substituting soybean meal for urea in diets based on deferred buffelgrass on the performance of feedlot sheep. Thirty mixed-breed sheep with an average initial body weight of $17 \pm 1.5 \mathrm{~kg}$ were distributed in a completely randomized design in which the experimental treatments consisted of five diets with six replicates. Diets were composed of deferred buffelgrass plus concentrates and calculated to be isoproteic. Treatments were represented by the substitution of soybean meal for the urea levels $(0,25,50,75$, and 100\%). Nutrient intake did not differ among animals fed diets with urea levels. Hot and cold carcass weights, hot and cold carcass dressing percentages, initial and final $\mathrm{pH}$, and weight of commercial cuts did not differ among animal fed diets with urea levels. There was no difference for non-carcass components among animals, except for the empty carcass, gall bladder, and perirenal fat weights, which were influenced by dietary urea levels. Substituting the crude protein from soybean meal for the protein from urea provides a similar performance in sheep consuming deferred buffelgrass.
\end{abstract}

Key Words: carcass quality, non-protein nitrogen, protein, standing hay

\section{Introduction}

In the semiarid climates, for animals to maintain an appropriate level of production throughout the year, highquality roughages must also be provided during the dry season, since the demand for feed is present all year long. Among the typical forage-preservation methods, haying is a process aimed at rapidly drying the material to prevent losses of carbohydrates and leaves; for this reason, the plant should ideally have fine stems so that its drying time is reduced (Castagnara et al., 2012).

One of the most prominent forage options for use during the feed-scarcity period for hay-making in the semiarid regions is buffelgrass (Cenchrus ciliares), a crop widely used for its biomass yield, dense leaves, fine stems that accumulate carbohydrates, and protein

Received: February 3, 2017

Accepted: September 18, 2017

*Corresponding author: gildenia-pereira@hotmail.com

Copyright (C) 2018 Sociedade Brasileira de Zootecnia. This is an Open Access article distributed under the terms of the Creative Commons Attribution License (http://creativecommons.org/licenses/by/4.0/), which permits unrestricted use, distribution, and reproduction in any medium, provided the original work is properly cited. content that ranges from 3.04 to $4.52 \%$, on a dry matter basis (Moreira et al., 2007).

In the specific case of semiarid climates, buffelgrass responds with an accelerated growth after rain events, ending its phenological cycle and forming inflorescences (Freitas et al., 2013). Subsequently, it enters senescence and rapidly loses its nutritional value. Voltolini et al. (2010), evaluating performance of sheep grazing deferred buffelgrass supplied with urea, verified no more than $47 \mathrm{~g}$ daily gain and stated this low performance is due to difficulty of grazing deferred buffelgrass because pasture had high stem:leaf ratio. Thus, the cut, processing, and use in feedlot could improve animal performance.

Plant-derived protein supplements, as is the case of soybean meal, are more expensive, which may incur higher feeding costs. Thus, urea, a source of non-protein nitrogen (NPN), is an option because, in addition to increasing the nitrogen and crude protein contents of the feed, it affects its digestibility, resulting in better animal performance.

However, the effects of substituting soybean meal as a true-protein source for urea have not been evaluated in sheep fed deferred buffelgrass hay in feedlot. Therefore, the present study was conducted to evaluate the performance 
and carcass yield of feedlot mixed-breed sheep fed diets containing deferred buffelgrass with levels of urea substituting true-protein sources derived from soybean meal. The replacement of soybean meal for urea does not affect animal performance.

\section{Material and Methods}

Research on animals was conducted according to the institutional committee on animal use (case no. 019/2016). The experiment was conducted in Pendência, located in Soledade, PB, Brazil ( $7^{\circ} 8^{\prime} 18^{\prime \prime} \mathrm{S}, 36^{\circ} 27^{\prime} 2^{\prime \prime} \mathrm{W}$, and $534 \mathrm{~m}$ asl). The experimental period was from September to October 2015. Thirty male crossbred Santa Ines sheep with an average initial weight of $17.0 \pm 1.5 \mathrm{~kg}$ were distributed in a completely randomized design, in which their weight was used as a co-variable and experimental treatments consisted of five diets with six replicates.

Different levels of NPN in sheep diet were tested in a completely randomized design. Diets were composed of deferred buffelgrass and concentrate and treatments were represented by the substitution of the crude protein (CP) from the true-protein source (soybean meal) of the diets for CP from the non-protein nitrogen source (urea), as follows: $0 \%$ substitution of CP from soybean meal for urea; $25 \%$ substitution of CP from soybean meal for urea; $50 \%$ substitution of CP from soybean meal for urea; $75 \%$ substitution of CP from soybean meal for urea; and 100\% substitution of $\mathrm{CP}$ from soybean meal for urea.

The buffelgrass was harvested in July 2015 from a closed pasture. The grass was harvested at $10 \mathrm{~cm}$ above the soil with a backpack mower; next, the material was transported to the experimental farm, where it was baled and stored in a shed where the experiment took place. Sheep were confined for 50 days, after a period of eight days of adaptation to management, facilities, and diets. Diets were provided ad libitum, supplied twice daily (at 07.00 and $15.00 \mathrm{~h}$ ), during the entire experimental period. Leftovers were adjusted to be approximately $20 \%$ of the total provided per animal.

Animals were weighed every 14 days, starting at the beginning of the experiment. On the first occasion, lambs were deprived of solid feed for $16 \mathrm{~h}$. Prior to the onset of the experiments, they were identified with numbered earrings, dewormed, weighed, distributed at random into their treatments, and housed in individual $2.0-\mathrm{m}^{2}$ stalls equipped with feeders and dinkers. Stalls were cleaned periodically.

Samples of feeds provided and leftovers were collected weekly to form composite samples corresponding to each experimental period. These were placed in aluminum trays and dried in an oven at $60{ }^{\circ} \mathrm{C}$ until reaching a constant weight for the determination of the pre-dried matter. Next, each sample was ground through a Wiley mill with $1 \mathrm{~mm}$ sieves, stored in a plastic container, and identified for later analyses of chemical components.

Dry matter (DM), crude protein (CP), mineral matter $(\mathrm{MM})$, and ether extract (EE) contents were determined following the methodology described by AOAC (1990) (Table 1). To determine the cell wall fraction, neutral detergent fiber (NDF), and acid detergent fiber (ADF), we employed the methodology described by Van Soest et al. (1991). Lignin was obtained from the ADF residue, based on the method described by Silva and Queiroz (2002), treated with $72 \%$ sulfuric acid. In all samples, NDF was corrected for ash and protein; for this, the residues from digestion in neutral and acid detergent were incinerated in a muffle furnace at $600{ }^{\circ} \mathrm{C}$ for $2 \mathrm{~h}$. Corrections for protein were performed using neutral detergent insoluble protein (NDIP) and the concentrations of non-fibrous carbohydrates (NFC), as recommended by Mertens (2002) and Licitra et al. (1996).

Diets were formulated to be isoproteic and to meet the requirements of the animals for an average daily gain of $200 \mathrm{~g}$, according to NRC (2007) for mixed-breed lambs (Table 2).

Lambs were weighed at the beginning of the experiment and every 14 days on a mechanical bench scale with a cage for small ruminants. The animals were weighed before the first meal, after being deprived of food for $16 \mathrm{~h}$, to monitor the evolution of their weight and their daily weight gain.

After the experimental period, the animals were weighed to obtain the final weight $(\mathrm{FW})$ and then deprived of solid feed for $16 \mathrm{~h}$. Subsequently, they were once again weighed to determine the slaughter weight (SW) for the calculation of fasting weight loss, using the following equation: $\mathrm{FWL}=(\mathrm{FW}-\mathrm{SW}) \times \mathrm{FW}$.

Table 1 - Chemical composition of ingredients of diets (in $\mathrm{g} \mathrm{kg}^{-1}$ dry matter)

\begin{tabular}{lcccc}
\hline \multirow{2}{*}{ Item } & \multicolumn{4}{c}{ Ingredient } \\
\cline { 2 - 5 } & $\begin{array}{c}\text { Deferred } \\
\text { buffelgras }\end{array}$ & $\begin{array}{c}\text { Soybean } \\
\text { meal }\end{array}$ & $\begin{array}{c}\text { Corn } \\
\text { bran }\end{array}$ & Urea \\
\hline Dry matter (g kg ${ }^{-1}$ fresh matter) & 822.0 & 866.2 & 857.1 & 99.0 \\
Organic matter & 911.2 & 944.5 & 986.0 & - \\
Crude protein & 41.4 & 452.7 & 95.4 & 281.3 \\
Ether extract & 7.3 & 19.6 & 53.7 & - \\
Neutral detergent fiber & 597.6 & 169.4 & 177.2 & - \\
Acid detergent fiber & 326.9 & 30.0 & 92.4 & - \\
Lignin & 52.9 & 13.3 & 11.6 & - \\
Acid detergent insoluble nitrogen & 6.4 & 6.8 & 17.3 & - \\
Neutral detergent insoluble nitrogen & 25.4 & 422.5 & 87.3 & - \\
\hline
\end{tabular}


Table 2 - Proportion of ingredients and chemical composition of experimental diets

\begin{tabular}{|c|c|c|c|c|c|}
\hline \multirow{2}{*}{ Item } & \multicolumn{5}{|c|}{ Experimental $\operatorname{diet}^{1}$} \\
\hline & $0 \%$ & $25 \%$ & $50 \%$ & $75 \%$ & $100 \%$ \\
\hline \multicolumn{6}{|c|}{ Proportion of ingredients ( $\mathrm{g} \mathrm{kg}^{-1}$ dry matter) } \\
\hline Deferred buffelgrass & 485.9 & 489.6 & 484.4 & 484.2 & 483.0 \\
\hline Corn & 360.5 & 382.7 & 413.8 & 440.0 & 463.1 \\
\hline Soybean & 125.2 & 92.3 & 59.5 & 27.7 & 00.0 \\
\hline Urea & 00.0 & 04.6 & 10.4 & 15.1 & 20.8 \\
\hline Ammonium chloride & 10.7 & 10.7 & 10.6 & 10.6 & 10.6 \\
\hline Mineral supplement ${ }^{2}$ & 16.6 & 18.9 & 20.1 & 21.3 & 22.5 \\
\hline Limestone & 01.2 & 01.2 & 01.2 & 01.2 & 00.0 \\
\hline \multicolumn{6}{|c|}{ Chemical composition ( $\mathrm{g} \mathrm{kg}^{-1}$ dry matter) } \\
\hline Dry matter ${ }^{3}$ & 844.2 & 844.5 & 845.1 & 845.5 & 845.9 \\
\hline Organic matter & 916.5 & 915.3 & 916.0 & 916.2 & 917.5 \\
\hline Mineral matter & 83.5 & 84.7 & 84.0 & 83.8 & 82.5 \\
\hline Crude protein & 131.7 & 131.3 & 134.6 & 135.0 & 140.2 \\
\hline Neutral detergent fiber ${ }^{4}$ & 375.5 & 376.0 & 372.9 & 372.0 & 370.7 \\
\hline Non-fibrous carbohydrates & 401.4 & 407.9 & 417.9 & 426.2 & 433.4 \\
\hline Ether extract & 25.4 & 26.0 & 27.0 & 27.7 & 28.5 \\
\hline
\end{tabular}

${ }^{1} 0,25,50,75$, and $100 \%$ substitution of the crude protein from soybean meal for urea.

${ }^{2}$ Mineral supplement (nutrient/kg supplement): vitamin A, 135,000 IU; vitamin D3, 68,000 IU; vitamin E, $450 \mathrm{IU}$; calcium, $240 \mathrm{~g}$; phosphorus, $71 \mathrm{~g}$; potassium, $28.2 \mathrm{~g}$; sulfur, $20 \mathrm{~g}$ plus sulfur from ammonium sulfate to maintain the $9: 1$ ratio (urea:ammonium sulfate); magnesium, $20 \mathrm{~g}$; copper, $400 \mathrm{mg}$; cobalt, $30 \mathrm{mg}$; chromium, $10 \mathrm{mg}$; iron, 2,500 mg; iodine, $40 \mathrm{mg}$; manganese, $1,350 \mathrm{mg}$; selenium, $15 \mathrm{mg}$; zinc, $1,700 \mathrm{mg}$; maximum fluorine, $710 \mathrm{mg}$; phosphorus solubility in $2 \%$ citric acid (minimum).

${ }^{3} \mathrm{~g} \mathrm{~kg}^{-1}$ fresh matter.

${ }^{4}$ Corrected for ash and protein.

Lambs were stunned by brain concussion using a captive bolt pistol; afterwards, they were bled by sectioning their jugular veins and carotid arteries. Later, the animals were skinned and eviscerated and their blood was collected in a tared container for subsequent weighing.

After skinning and evisceration, head and feet were removed to obtain the hot carcass weight (HCW). Gastrointestinal tract, bladder, and gall bladder were emptied and used in the determination of empty body weight, which was estimated by subtracting the weights of these organs from the slaughter weight (SW), to then determine the carcass dressing.

Next, the carcasses were cooled in a cold room for $24 \mathrm{~h}\left( \pm 2\right.$ to $\left.4{ }^{\circ} \mathrm{C}\right)$ and later weighed to determine the cold carcass weight $(\mathrm{CCW})$ and cooling loss $[\mathrm{CL}=(\mathrm{HCW}-$ $\mathrm{CCW} / \mathrm{HCW} \times 100]$.

The following morphometric measurements were taken on the carcass, as indicated by Garcia et al. (2003): chest and rump widths, chest depth, heart girth, rump circumference, leg circumference, internal and external carcass lengths, and leg length.

Carcasses were assessed subjectively for conformation, by assigning the scores 1 = poor (concave), 2 = regular (subconcave), $3=\operatorname{good}($ straight), $4=$ very good (sub-convex), and $5=$ excellent (convex), and for fatness degree (scores $1=$ too lean, $2=$ lean, $3=$ medium, $4=$ fat, and $5=$ too fat), as proposed by Cezar and Sousa (2007). In the evaluation of the carcass pelvic-renal fat, scores from 1 to 3 were assigned, as follows: $1=$ little (both kidneys uncovered), $2=$ normal (one kidney covered), and 3 = excessive (both kidneys covered).

After the subjective assessment of the carcass pelvicrenal fat, the kidneys and pelvic + renal fat were removed and their weights were recorded and subtracted from the hot and cold carcass weights. Next, the hot and cold carcass dressing percentages were calculated by the following equations: $\mathrm{HCD}=(\mathrm{HCW} / \mathrm{SW}) \times 100$ and $\mathrm{CCD}=(\mathrm{CCW} / \mathrm{SW}) \times 100$.

Carcasses were divided lengthwise, along the midline, and the left half-carcasses were weighed and sectioned into the following five regions: shoulder - obtained by sectioning the axillary region by cutting the tissues joining the scapula and humerus to the thoracic region of the carcass; ribs - resulting from two sections: the first between the last cervical and the first thoracic vertebrae and the second between the last thoracic and the first lumbar vertebrae; loin - obtained by two sections: one between the last thoracic and the first lumbar vertebrae and another between the last lumbar and the first sacral vertebrae; neck and leg - separated from the carcass at its upper end between the last lumbar and the first sacral. As the cuts were removed from the carcass, they were immediately weighed, as described in Gonzaga Neto et al. (2006).

The carcass was sectioned in half using a bandsaw (SF 42, G. paniz). A cross-section was made in the left half-carcass between the 12th and 13th ribs, exposing the transverse section of the longissimus dorsi muscle, whose area was outlined using an appropriate pen onto a transparent plastic film to determine the loin-eye area.

A regression analysis was applied to identify effect of NPN levels on all variables in study, with a 5\% significance level. Linear and quadratic polynomials were tested. Statistical Analysis System software, version 9.2, was used, following statistical model:

$$
y_{i j}=\mu+\alpha_{i}(\tau)+e_{i j}
$$

in which $y_{i j}$ is the observed value for a dependent variable in the $i j$-th sample; $\mu$ is de average value for this variable; is the regression effect of the $\tau(0,25,50,75$, and $100 \%$ substitution of soybean meal for urea); and $e_{i j}$ is the random residual term.

\section{Results}

The intakes of DM, organic matter, CP, NDF, EE, and NFC, feed conversion, and feed efficiency did not differ among animals receiving urea levels (Table 3). The DM intake of the animals in the present study was, on average, $903.77 \mathrm{~g} \mathrm{~d}^{-1}$. 
None of the performance parameters (SW, total weight gain (TWG), ADG, HCW, CCW, HCD, and CCD) differed among the animals receiving diets with urea levels (Table 4). In this way, the mean values for SW, TWG, ADG, FC, and FE were $28.53 \mathrm{~kg}, 8.76 \mathrm{~kg}, 175.23 \mathrm{~g} \mathrm{~d}^{-1}$, $5.64 \mathrm{~kg} \mathrm{DM} \mathrm{kg}^{-1} \mathrm{ADG}$, and $194.34 \mathrm{~g} \mathrm{ADG} \mathrm{kg}^{-1} \mathrm{DM}$, respectively. Mean values for $\mathrm{HCW}, \mathrm{CCW}, \mathrm{HCD}$, and CCD were $13.13 \mathrm{~kg}, 12.87 \mathrm{~kg}, 42.30 \mathrm{~kg} / 100 \mathrm{~kg}$ of body weight (BW), and $41.36 \mathrm{~kg} / 100 \mathrm{~kg} \mathrm{BW}$, respectively.

Although the ADG of the animals fed diets with urea did not differ statistically from that of the animals receiving $0 \%$ urea, it was lower than the $200 \mathrm{~g}$ established when the diets were formulated.

The use of urea only as the main source of protein at up to $2.08 \%$ in the dietary dry matter did not cause any nutritional disturbances and provided similar performance and carcass quality to sheep fed soybean meal as the main source of CP (Table 4). The substitution of soybean meal for urea in sheep feeding can thus be a viable alternative, as it lowers production costs, allowing the producer to have a better gross margin.
The morphometric measurements of the sheep did not differ with the urea inclusion levels (Table 5), except internal carcass length, which increased linearly $(\mathrm{P}<0.05)$. This result can be explained by the age of the animals, which did not allow for a greater bone tissue growth, thereby preventing further measurements on the carcass.

The lack of effect of nitrogen sources on the intakes of DM and nutrients led to similar performances among the sheep consuming deferred buffelgrass (Tables 3 and 4). Likewise, their similar performance provided similarities in their carcass morphometry and in most of the carcass and non-carcass components (Tables 5, 6, 7, and 8).

Lambs fed the diets containing urea displayed no differences in gall bladder weight (Table 8 ), likely because of their EE intake (Table 3).

Cooling loss, carcass dressing, and loin-eye area did not differ among animals fed the urea inclusion levels (Table 6). The average CL, carcass dressing, and loin-eye area values were $1.92 \mathrm{~kg} / 100 \mathrm{~kg} \mathrm{BW}, 0.55 \mathrm{~kg} / 100 \mathrm{~kg} \mathrm{BW}$, and $7.83 \mathrm{~cm}^{2}$, respectively.

Table 3 - Nutrient intake by sheep fed diets with deferred buffelgrass and different proportions of true protein and non-protein nitrogen

\begin{tabular}{|c|c|c|c|c|c|c|c|c|}
\hline \multirow{2}{*}{ Intake } & \multicolumn{5}{|c|}{$\operatorname{Diet}^{1}$} & \multirow{2}{*}{ SEM } & \multicolumn{2}{|c|}{ P-value } \\
\hline & $0 \%$ & $25 \%$ & $50 \%$ & $75 \%$ & $100 \%$ & & $\mathrm{~L}$ & Q \\
\hline Dry matter $\left(\mathrm{g} \mathrm{d}^{-1}\right)$ & 907.76 & 980.21 & 817.80 & 953.40 & 859.65 & 27.3775 & 0.9713 & 0.8819 \\
\hline Dry matter $\left(\mathrm{g} \mathrm{kg}^{-1} \mathrm{~d}^{-1} \mathrm{BW}\right)$ & 35.73 & 36.75 & 33.15 & 37.35 & 34.28 & 0.5352 & 0.9260 & 0.9354 \\
\hline Organic matter $\left(\mathrm{g} \mathrm{d}^{-1}\right)$ & 837.31 & 899.87 & 750.07 & 876.93 & 794.38 & 25.1477 & 0.9119 & 0.9491 \\
\hline Crude protein $\left(\mathrm{g} \mathrm{d}^{-1}\right)$ & 115.67 & 126.63 & 112.24 & 130.32 & 123.32 & 3.7227 & 0.7588 & 0.9130 \\
\hline $\operatorname{NDF}\left(\mathrm{g} \mathrm{d}^{-1}\right)$ & 300.54 & 348.71 & 269.02 & 330.99 & 290.42 & 11.5421 & 0.8246 & 0.7137 \\
\hline $\operatorname{NDF}\left(\mathrm{g} \mathrm{kg}^{-1} \mathrm{~d}^{-1} \mathrm{BW}\right)$ & 11.71 & 13.05 & 10.86 & 12.96 & 11.58 & 0.2761 & 0.6743 & 0.6240 \\
\hline Ether extract $\left(\mathrm{g} \mathrm{d}^{-1}\right)$ & 22.54 & 22.48 & 21.97 & 26.54 & 25.40 & 0.7573 & 0.7151 & 0.9915 \\
\hline $\operatorname{NFC}\left(\mathrm{g} \mathrm{d}^{-1}\right)$ & 396.02 & 425.21 & 380.48 & 437.24 & 406.00 & 11.3348 & 0.7597 & 0.8396 \\
\hline Feed conversion $\left(\mathrm{kg} \mathrm{kg}^{-1}\right)$ & 4.79 & 5.30 & 7.03 & 5.38 & 5.70 & 0.4733 & 0.2943 & 0.3517 \\
\hline Feed efficiency $\left(\mathrm{g} \mathrm{kg}^{-1}\right)$ & 217.44 & 195.42 & 182.02 & 194.23 & 182.56 & 8.9872 & 0.3729 & 0.5436 \\
\hline
\end{tabular}

BW - body weight; NDF - neutral detergent fiber; NFC - non-fibrous carbohydrates; SEM - standard error of the mean; L - linear; Q - quadratic.

${ }^{1} 0,25,50,75$, and $100 \%$ substitution of the crude protein from soybean meal for urea

Table 4 - Performance of sheep fed diets with deferred buffelgrass and different proportions of true protein and non-protein nitrogen

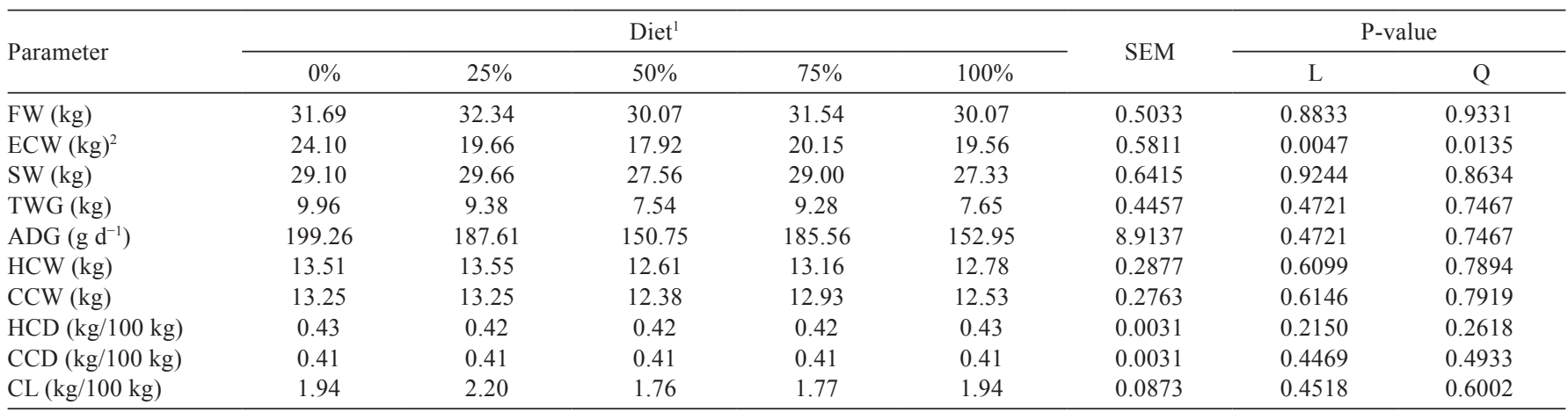

FW - final weight; ECW - empty carcass weight; SW - slaughter weight; TWG - total weight gain; ADG - average daily gain; HCW - hot carcass weight; CCW - cold carcass weight; HCD - hot carcass dressing; CCD - cold carcass dressing; CL - cooling loss; SEM - standard error of the mean; L - linear; Q - quadratic.

${ }^{1} 0,25,50,75$, and $100 \%$ substitution of the crude protein from soybean meal for urea

${ }^{2} \hat{\mathrm{Y}}=-0.0295 \mathrm{X}+21.755\left(\mathrm{r}^{2}=0.29\right)$ 
Table 5 - Morphometric measurements of the carcass of sheep fed diets with deferred buffelgrass and different proportions of true protein and non-protein nitrogen

\begin{tabular}{|c|c|c|c|c|c|c|c|c|}
\hline \multirow{2}{*}{ Parameter $(\mathrm{cm})$} & \multicolumn{5}{|c|}{$\operatorname{Diet}^{1}$} & \multirow{2}{*}{ SEM } & \multicolumn{2}{|c|}{ P-value } \\
\hline & $0 \%$ & $25 \%$ & $50 \%$ & $75 \%$ & $100 \%$ & & $\mathrm{~L}$ & Q \\
\hline Internal carcass length & 58.76 & 57.85 & 58.16 & 58.64 & 59.39 & 0.2852 & 0.3217 & 0.1595 \\
\hline Chest width & 14.33 & 13.83 & 13.33 & 13.33 & 13.16 & 0.1857 & 0.0078 & 0.3421 \\
\hline Rump width & 18.33 & 18.00 & 17.33 & 17.83 & 17.83 & 0.2148 & 0.4319 & 0.2854 \\
\hline Chest depth & 25.87 & 25.89 & 26.30 & 26.10 & 26.82 & 0.1370 & 0.1200 & 0.6182 \\
\hline Rump circumference & 55.16 & 54.33 & 52.66 & 53.16 & 52.50 & 0.6489 & 0.4070 & 0.6492 \\
\hline Leg circumference & 34.33 & 33.33 & 31.83 & 33.00 & 34.16 & 0.4005 & 0.0490 & 0.0471 \\
\hline Leg length & 39.08 & 39.25 & 40.33 & 39.68 & 40.08 & 0.2943 & 0.2913 & 0.7673 \\
\hline
\end{tabular}

SEM - standard error of the mean; L - linear; Q - quadratic.

${ }^{1} 0,25,50,75$, and $100 \%$ substitution of the crude protein from soybean meal for urea.

Table 6 - Quantitative traits of the carcass of sheep fed diets with deferred buffelgrass and different proportions of true protein and nonprotein nitrogen

\begin{tabular}{|c|c|c|c|c|c|c|c|c|}
\hline \multirow{2}{*}{ Parameter } & \multicolumn{5}{|c|}{ Diet $^{1}$} & \multirow{2}{*}{ SEM } & \multicolumn{2}{|c|}{ P-value } \\
\hline & $0 \%$ & $25 \%$ & $50 \%$ & $75 \%$ & $100 \%$ & & $\mathrm{~L}$ & Q \\
\hline Carcass dressing $(\mathrm{kg} / 100 \mathrm{~kg})$ & 0.57 & 0.72 & 0.71 & 0.67 & 0.65 & 0.0271 & 0.1058 & 0.1289 \\
\hline Loin-eye area $\left(\mathrm{cm}^{2}\right)$ & 7.78 & 7.88 & 7.14 & 8.54 & 6.83 & 0.2481 & 0.6386 & 0.4869 \\
\hline Initial temperature $\left({ }^{\circ} \mathrm{C}\right)^{2}$ & 32.06 & 33.73 & 32.91 & 33.86 & 34.50 & 0.2115 & 0.0032 & 0.8745 \\
\hline Final temperature $\left({ }^{\circ} \mathrm{C}\right)^{3}$ & 5.98 & 6.01 & 7.21 & 7.30 & 8.73 & 0.1543 & $<.0001$ & 0.1742 \\
\hline Initial $\mathrm{pH}$ & 6.66 & 6.71 & 6.76 & 6.63 & 6.72 & 0.0221 & 0.5998 & 0.6188 \\
\hline Final $\mathrm{pH}$ & 5.82 & 5.74 & 5.73 & 5.75 & 5.68 & 0.0344 & 0.6351 & 0.8684 \\
\hline
\end{tabular}

SEM - standard error of the mean; L - linear; Q - quadratic.

${ }^{1} 0,25,50,75$, and $100 \%$ substitution of the crude protein from soybean meal for urea.

${ }^{2} \hat{\mathrm{Y}}=0.02 \mathrm{X}+32.417\left(\mathrm{r}^{2}=0.27\right)$

${ }^{3} \hat{Y}=0.0271 X+5.693\left(r^{2}=0.26\right)$.

Table 7 - Weight of commercial cuts from the carcass of sheep fed diets containing deferred buffelgrass and ratios between true protein and non-protein nitrogen

\begin{tabular}{|c|c|c|c|c|c|c|c|c|}
\hline \multirow{2}{*}{ Parameter } & \multicolumn{5}{|c|}{$\operatorname{Diet}^{1}$} & \multirow{2}{*}{ SEM } & \multicolumn{2}{|c|}{ P-value } \\
\hline & $0 \%$ & $25 \%$ & $50 \%$ & $75 \%$ & $100 \%$ & & $\mathrm{~L}$ & Q \\
\hline Cold half-carcass weight (kg) & 6.76 & 6.50 & 6.16 & 6.49 & 6.26 & 0.0768 & 0.0723 & 0.2714 \\
\hline Neck (kg) & 1.00 & 1.07 & 1.04 & 1.09 & 1.09 & 0.0218 & 0.6632 & 0.7784 \\
\hline Shoulder (kg) & 1.19 & 1.17 & 1.20 & 1.12 & 1.19 & 0.0137 & 0.6761 & 0.9019 \\
\hline Ribs (kg) & 1.63 & 1.69 & 1.80 & 1.67 & 1.72 & 0.0253 & 0.4740 & 0.4058 \\
\hline Loin (kg) & 0.72 & 0.74 & 0.70 & 0.77 & 0.71 & 0.0112 & 0.8444 & 0.6571 \\
\hline Leg $(\mathrm{kg})$ & 2.13 & 2.06 & 2.05 & 2.08 & 2.13 & 0.0112 & 0.4504 & 0.5736 \\
\hline \multicolumn{9}{|l|}{ Yield $(\mathrm{kg} / 100 \mathrm{~kg})$ of $\mathrm{BW}$} \\
\hline Neck (kg/100 kg) & 15.28 & 16.59 & 16.49 & 16.98 & 16.90 & 0.3194 & 0.1198 & 0.4151 \\
\hline Shoulder $(\mathrm{kg} / 100 \mathrm{~kg})$ & 18.35 & 18.25 & 18.69 & 17.64 & 18.19 & 0.1750 & 0.4557 & 0.9178 \\
\hline Ribs (kg/100 kg) & 25.02 & 26.72 & 28.00 & 26.12 & 26.21 & 0.3435 & 0.4769 & 0.0600 \\
\hline Loin (kg/100 kg) & 11.07 & 11.70 & 10.69 & 12.09 & 10.73 & 0.1847 & 0.8188 & 0.3298 \\
\hline Leg (kg/100 kg) & 32.67 & 32.05 & 32.26 & 32.72 & 32.82 & 0.2366 & 0.5414 & 0.4615 \\
\hline
\end{tabular}

BW - body weight; SEM - standard error of the mean; L - linear; Q - quadratic.

${ }^{1} 0,25,50,75$, and $100 \%$ substitution of the crude protein from soybean meal for urea.

Table 8 - Subjective assessment and thickness of fat from carcasses of mixed-breed sheep fed diets containing deferred buffelgrass and sources of non-protein nitrogen

\begin{tabular}{|c|c|c|c|c|c|c|c|c|}
\hline \multirow{2}{*}{ Parameter } & \multicolumn{5}{|c|}{ Diet $^{1}$} & \multirow{2}{*}{ SEM } & \multicolumn{2}{|c|}{ P-value } \\
\hline & $0 \%$ & $25 \%$ & $50 \%$ & $75 \%$ & $100 \%$ & & $\mathrm{~L}$ & Q \\
\hline Renal fat $(\mathrm{kg} / 100 \mathrm{~kg})$ & 0.26 & 0.31 & 0.24 & 0.29 & 0.32 & 0.0139 & 0.1269 & 0.1650 \\
\hline Pelvic fat $(\mathrm{kg} / 100 \mathrm{~kg})^{2}$ & 0.05 & 0.06 & 0.03 & 0.03 & 0.04 & 0.0031 & 0.0069 & 0.0576 \\
\hline Inguinal fat $(\mathrm{kg} / 100 \mathrm{~kg})$ & 0.08 & 0.11 & 0.07 & 0.09 & 0.08 & 0.0057 & 0.6942 & 0.5544 \\
\hline Conformation $(1-5)^{3}$ & 3.00 & 3.08 & 2.88 & 2.73 & 2.68 & 0.0354 & 0.0229 & 0.3106 \\
\hline Degree of fatness $(1-5)^{4}$ & 3.00 & 3.08 & 2.88 & 2.73 & 2.68 & 0.0699 & 0.0007 & 0.4062 \\
\hline
\end{tabular}

SEM - standard error of the mean; L - linear; Q - quadratic.

${ }^{1} 0,25,50,75$, and $100 \%$ substitution of the crude protein from soybean meal for urea.

${ }^{2} \hat{\mathrm{Y}}=0.0003 \mathrm{X}+0.0533\left(\mathrm{r}^{2}=0.22\right)$.

${ }^{3} \hat{Y}=-0.0032 X+2.9567\left(r^{2}=0.18\right)$

${ }^{4} \hat{\mathrm{Y}}=-0.0039 \mathrm{X}+3.0733\left(\mathrm{r}^{2}=0.34\right)$. 
The initial temperature of the carcasses and the degree of fatness of the animals were not different $(\mathrm{P}>0.05)$ among urea levels. The weights of the commercial cuts from the carcasses of the animals fed urea levels did not show significant differences, either. Of all evaluated cuts, the leg showed the highest weight and yield, which ranged from 2.16 to $1.99 \mathrm{~kg}$ and 31.90 to $32.85 \mathrm{~kg} / 100 \mathrm{~kg} \mathrm{BW}$, respectively (Table 7).

Commercial cuts from the carcasses of animals fed urea inclusion levels did not differ (Table 7). Cuts considered first-class (leg and loin) accounted for 41.67 $\mathrm{kg} / 100 \mathrm{~kg}$, while second-class cuts (shoulder) represented $17.41 \mathrm{~kg} / 100 \mathrm{~kg}$, and third-class cuts (neck and ribs) were $40.98 \mathrm{~kg} / 100 \mathrm{~kg}$ of the total left half-carcass. Therefore, the cuts of greatest commercial importance, considered first- and second-class, which are valued by the consumer, had a higher participation in the carcass. There was also a linear effect of diets on pelvic fat and carcass conformation with reduction when urea was increased (Table 8). The influence of diets containing higher protein content from urea on the lower pelvic fat (Table 8) demonstrates that the animals that consumed them had a lower degree of fatness than those fed soybean meal only. As a consequence, the carcasses of lambs consuming more protein from urea had a worse conformation.

No effect of the diets was observed $(\mathrm{P}>0.05)$ on the average urea and glucose values (Table 9).

\section{Discussion}

The DM intake of the animals in the present study was, on average, $33.9 \%$ higher than the $43 \mathrm{~g} \mathrm{~kg}^{-1} \mathrm{~d}^{-1} \mathrm{BW}$, recommended by NRC (2007) for sheep with the same body weight and weight gain. The $\mathrm{CP}$ requirements recommended by the same institute for these animals, however, was $98.25 \mathrm{~g}$ (Table 3); these requirements were met by the animals, probably because DM intake was higher than estimated.

When associated with a low-quality roughage, inclusion of rumen-degradable protein in the diet has a positive effect on the intakes of DM and $\mathrm{CP}$, which can be attributed to the adequate nitrogen uptake for the activity of rumen microorganisms (Azevedo et al., 2008). To reach ideal level of NPN to increase microbial protein, the ruminants increase the intake (Chandrasekharaiah et al., 2011). This intake level can be changed by a physical distension of the rumen brought about by NDF (Dado and Allen, 1995). However, the urea inclusion did not increase the nutrient intake by animals (Table 3). According to Van Soest (1994), an NDF intake between 0.8 and $1.2 \%$ body weight maximizes DM intake. The average NDF intake among the treatments was within this range and, thus, intake was maximized, as the animals were not under physical limitation. Thus, dry matter intake by animals of the treatment without urea was probably maximized and it was not possible to increase dry matter intake of animals fed diets with urea. The maximum urea inclusion level was $2.08 \%$, on a dry matter basis (Table 2 ). According to Gallo et al. (2015), supplementation with urea must not exceed $2 \%$ of the total diet. These authors stated that values higher than those lead to a decrease in feed intake as well as in animal performance. However, none of the urea-containing diets limited DM (g/day) or organic matter $(\mathrm{OM})(\mathrm{g} /$ day) intake by the animals (Table 3$)$. It is thus observed that true-protein sources (soybean meal) can be substituted for NPN sources (urea) without compromising the animal intake.

The ammonia not used for protein synthesis in the rumen is absorbed and carried out to blood coming at the liver and then converted into urea. Thus, the blood urea level is an indicator of nitrogen not used in the rumen (Alves et al., 2012). In the present study, there was no difference among treatments for blood urea concentration; therefore, the efficiency of rumen urea use was similar among treatments.

The recommended values of urea blood for sheep range from 24 to $60 \mathrm{mg} \mathrm{dL}^{-1}$ (González and Silva, 2006). The observed values in the present study were according to these authors (Table 9) and indicates that inclusion of up to $2.08 \%$ urea in the diet does not decrease animal performance due to the correct protein and energy ratio to be maintained. Mendes et al. (2010) evaluated the partial substitution of soybean meal for urea or starea in the feeding of lactating

Table 9 - Mean values for plasma urea and glucose concentrations of mixed-breed sheep fed diets containing deferred buffelgrass and sources of non-protein nitrogen

\begin{tabular}{|c|c|c|c|c|c|c|c|c|}
\hline \multirow{2}{*}{ Item } & \multicolumn{5}{|c|}{$\operatorname{Diet}^{1}$} & \multirow{2}{*}{ SEM } & \multicolumn{2}{|c|}{$\mathrm{P}$-value } \\
\hline & $0 \%$ & $25 \%$ & $50 \%$ & $75 \%$ & $100 \%$ & & $\mathrm{~L}$ & Q \\
\hline Urea $\left(\mathrm{mg} \mathrm{dL}^{-1}\right)$ & 44.00 & 56.40 & 52.00 & 57.20 & 52.60 & 2.1913 & 0.1583 & 0.2386 \\
\hline Glucose $\left(\mathrm{mg} \mathrm{dL}^{-1}\right)$ & 77.00 & 78.60 & 69.80 & 76.80 & 66.40 & 2.1000 & 0.9941 & 0.6746 \\
\hline
\end{tabular}

SEM - standard error of the mean; L - linear; Q - quadratic.

${ }^{1} 0,25,50,75$, and $100 \%$ substitution of the crude protein from soybean meal for urea. 
goats and also obtained no statistical differences for the intakes of dry matter, crude protein, or neutral detergent fiber. These authors observed a dry matter intake relative to live weight ranging from 33.1 to $35.0 \mathrm{~g} / \mathrm{kg} \mathrm{BW}$, which are similar to the 33.2 to $33.7 \mathrm{~g} / \mathrm{kg} \mathrm{BW}$ found in the present experiment.

Alves et al. (2012) investigated the association of mesquite pod meal with urea levels in the feeding of sheep (nitrogen balance, plasma urea $\mathrm{N}$, and rumen parameters) and also observed that addition of urea at up to $1.5 \%$ (DM basis) did not influence nutrient intake. These findings corroborate Paixão et al. (2006), who stated that dry matter intake will not be influenced by urea inclusion in the diet, provided that the protein requirement is met. This effect was also observed by Azevedo et al. (2015), who used slow-release urea substituting soybean meal in the finishing of feedlot cattle and did not observe alterations in their dry matter intake.

The main carbohydrate-fermenting rumen microorganisms need ammonia for the synthesis of amino acids; ammonia may originate from true-protein sources and also NPN (Berchielli et al., 2011). Thus, fermentation of fibrous carbohydrates in the rumen will only be maximized if the ammonia requirement of rumen microorganisms is met (Valadares Filho and Pina, 2011). Detmann et al. (2011) studied the in vitro degradation of neutral detergent fiber of low-quality tropical forage and reported that NPN sources benefited the fiber-degrading microorganisms as compared with true-protein sources. Therefore, addition of urea to roughages with low nutritional value improves the potentially digestible NDF. The higher NDF digestibility increases the passage rate of digesta, allowing for a faster rumen emptying and providing an increase in DM and, consequently, nutrient intake.

Similar results were found by Moraes et al. (2012), who studied the intake and digestibility of nutrients in cattle receiving different urea levels and observed an increase in the intakes of DM and NDF as urea was added to the diet. As stated by these authors, when NPN sources are added, the energy uptake from the diet must be increased to allow an appropriate rumen function, which can be attributed to the maximization of microbial protein synthesis. However, there was no improvement in the intakes of DM and nutrients by the animals with addition of urea in diets. The surplus ammonia produced in the rumen was likely not used by the fibrolytic microorganisms for microbial synthesis and consequently did not provide a higher degradation rate of fibrous carbohydrates.

Detmann et al. (2011) and Moraes et al. (2012) used Brachiaria decumbens with high lignin content, which resulted in higher indigestible fiber. In the present study, we used the deferred buffelgrass, which is a fast-growing grass and presents lower lignin content (Table 1) (Santos et al., 2005); hence, NPN inclusion did not increase dry matter intake because it did not increase the digestibility of buffelgrass.

In addition, Costa et al. (2009) found that, in the presence of starch, the degradation of potentially digestible NDF is reduced. According to these authors, the microorganisms responsible for the degradation of NFC grow faster than the fibrous carbohydrate-fermenting microorganisms, capturing ammonia more quickly and slowing the potentially digestible NDF degradation process. Therefore, the higher NFC content originating from corn might have affected the degradation of fibrous carbohydrates.

The absence of effect for fiber degradation rate leads to a similar passage rate of digesta and, consequently, does not have a positive effect on the intakes of dry matter and nutrients. Rezende et al. (2008) studied the intake and digestibility of Brachiaria grass hay in cattle fed diet supplemented with urea and observed that increasing the CP level originating from the dietary NPN from 6.3 to $14.8 \%$ did not result in higher DM and NDF intakes.

This was probably a consequence of the $\mathrm{N}$ availability in the rumen environment for the microorganisms to increase microbial efficiency, thereby maximizing the degradability and digestibility of the fiber, directly affecting the rumination time, and reducing the feed particle size to facilitate the degradation process, since the fiber content and its physical form are the main factors affecting the rumination process (Alves et al., 2009). This may be attributed to the balanced ruminal concentration of ammonia from nitrogen compounds used in the diets and the source of fermentable carbohydrates that provided similar ADG among the animals receiving the different NPN levels, which in turn might have been caused by a lower uptake of rumen undegradable protein (RUP) and the fact that the intestine limited the animal performance due to lack of metabolizable protein.

The sheep used in the present study were mixed-breed, which might also have influenced their ADG results, given that animal performance is highly correlated with nutrition and genetics. As previously mentioned, all diets tested in the present study met the $\mathrm{CP}$ requirements of the animals. Since the fiber digestion was not influenced by NPN in the rumen, animal performance would be associated with metabolic events, mainly $\mathrm{CP}$ and energy requirements.

According to Araújo Filho et al. (2015), the fat content present in the carcass is an indication of the energy reserve, 
used mainly when there is a feed deficit. However, young animals tend to deposit more muscle than fat. This fat content is a very important variable, as it directly influences the carcass dressing percentage.

In addition to a high proportion of muscles, carcasses considered good-quality should present an adequate amount of intermuscular fat to ensure meat juiciness and tenderness, as well as a good amount of subcutaneous fat to prevent excessive moisture loss during the entire cooling period. Sheep will only deposit intermuscular and subcutaneous fat after depositing abdominal adipose tissues like pelvic fat (Bezerra et al., 2012).

All carcasses displayed conformation ranging between 2.68 and 3.02, which, according to Cezar and Sousa (2007), characterizes carcasses as lean to medium conformation. Considering the breed of the animals of the present study, which does not allow for conformations greater than medium (Costa et al., 2013), and the market in Northeastern Brazil, these animals showed the minimum required traits.

The substitution of soybean meal for urea did influence the fat deposition in the carcass, which can determine a higher or lower percentage of loss according to its thickness. Therefore, our results demonstrate that there was imbalance between the protein and energy sources of the diet. This provided uniformity among the slaughtered animals, making it an important parameter for the sale of the end product.

Young animals typically show a higher metabolizable protein requirement and, although it is speculated that protein can be better used when diets containing a larger amount of RUP are included, lambs showed to make good use of the rumen degradable protein. This fact contradicts the NRC (1985) statement that lambs are an animal category that requires rumen undegradable protein to bear high growth rates (Mendes et al., 2006). Another important point for consideration is the roughage source used, when working with a basal forage resource. Mean values for carcass dressing and loin-eye area were $0.55 \mathrm{~kg} / 100 \mathrm{~kg}$ and $7.83 \mathrm{~cm}^{2}$, respectively; these did not differ $(\mathrm{P}>0.05)$ among lambs receiving diets with urea inclusion levels.

Lambs that consumed the highest levels of urea showed a linear increase temperature and worse carcass conformation. The temperature rise was a result of the amount of fat in the carcass, as it is known that the carcass temperature is directly related to the amount of fat present in the carcass. The carcass conformation was influenced by the urea levels. This inferior carcass conformation may be associated with the ruminal and metabolic efficiency of the animal, given that the use of nitrogen by rumen microorganisms is linked to the release of ammonia originating from the hydrolysis of urea and presence of energy for microbial synthesis. The hydrolysis occurs rapidly and efficiently, mostly leading to nitrogen losses through urea. For this reason, diets should be formulated to have an adequate source of protein and energy so the animal can obtain a better nitrogen use (Alves et al., 2012).

The complex effects of nitrogen on animal production are increased when its metabolic availability has a direct impact on the use of metabolizable energy. The nitrogen retention in the animal body reflects in the efficiency of use of all substrates involved in the composition of body and products, resulting in weight gain and production in general. The metabolic priorities of nitrogen compounds can be understood through an evaluation of the nitrogen balance in the rumen. Some studies have found negative hypotheses for nitrogen balance in the rumen, meaning the flow of nitrogen towards the abomasum is greater than the nitrogen intake. In this way, there will be a greater dependence on cycling so that the nitrogen in the rumen environment can be better used. This implies inefficient use of metabolizable protein for gain and an increased rate of mobilization of muscle protein to meet the nitrogen requirements of greater priority, culminating in low efficiency of the dietary nitrogen (Detmann et al., 2014).

However, substitution of protein meals for urea changes the amount of minerals available for rumen microorganisms and for the animal. The sulfur added as supplement may be less available than that naturally existing in the protein (NRC, 1976).

Given the foregoing, we can state that, after a certain level, the protein was probably not converted to muscle, thereby compromising the carcass conformation. This was probably because urea exceeded its ability to produce microbial protein that reaches the post-rumen to be absorbed by the animal, leading to a metabolic delay in muscle protein formation.

In addition to a good proportion of muscle, good-quality carcasses should have an adequate amount of intermuscular fat to ensure the juiciness and tenderness of meat, as well as an ideal amount of subcutaneous fat, which prevents excessive moisture losses during the cooling process (Bezerra et al., 2012).

Nevertheless, accumulation of fat in the carcass leads to a high requirement or positive balance of energy in the diet, causing this nutrient to be used reasonably in the production system. Excess fat - either subcutaneous or visceral - implies waste. However, the thin fat layer in the carcass means insufficient energy uptake, revealing insufficient productivity. The amount of subcutaneous fat is of great value because it reduces drip losses and maintains 
the good aspect of meat during cooling, in addition to preventing dryness and anomalies related to rigor mortis (Araújo Filho et al., 2015).

The diets provided the desired results from the nutritional standpoint and also from the metabolic perspective, which would be conversion of nutrients into meat. However, because of the protein and energy imbalance, the animal may come to accumulate fat without accumulating muscle, causing the carcass characteristics to be possibly compromised, since animals may obtain the same gain, consisting of fat accumulation only, rather than protein conversion into muscle.

Voltolini et al. (2011) studied the yield of commercial cuts and non-carcass components of lambs receiving increasing levels of concentrate, kept on a buffelgrass pasture, and fed a diet formulated with $20 \%$ crude protein and $75 \%$ total digestible nutrients, and observed that this diet did not affect carcass weight, but influenced the carcass yield of these animals.

Silva et al. (2010) evaluated the effect of supplementation on the tissue composition of commercial cuts from F1 (Boer $\times$ mixed breed) crossbred goats finished on a native pasture, receiving supplementation levels (0.0, $0.5,1.0$, and $1.5 \%$ live weight, on a dry matter basis), and slaughtered at $25.12,26.62,28.56$, and $29.19 \mathrm{~kg}$, respectively, and observed that, as the supplementation levels were increased, slaughter weight also increased. Additionally, these authors observed an adequate degree of fatness at the supplementation levels of 1.0 and $1.5 \%$, resulting in lower losses during the carcass cooling. However, slaughtering these animals at a younger age and at a lower live weight may be a viable alternative, since their meat has excellent quality and a lower cost to the producer, given the reduced permanence of the animal on the farm (Yáñez et al., 2009).

The subcutaneous fat provides better carcass maintenance, with fewer changes in $\mathrm{pH}$ and temperature (Marques et al., 2014). Thus, the animals that consumed more urea had a higher final carcass temperature due to the lower degree of fatness (Tables 6 and 9).

Similar results were found by Xenofonte et al. (2009), who observed, among all cuts, highest weight and yield for the leg, which ranged from 1.23 to $2.29 \mathrm{~kg}$ and 33.12 to $33.32 \%$, respectively, in mixed-breed lambs, representing a larger amount of muscle for sale.

Deferred buffelgrass hay, despite the low CP content, is a fiber source of better digestibility than other grasses at the same phenological stage and similar protein levels. This is due to its low lignin content, which probably allowed a higher ruminal digestion speed and favored the growth of fermenting fibrous carbohydrate microorganisms, due to the greater amount of energy availability in the rumen. Thus, the performance of sheep fed diets with deferred buffelgrass hay does not undergo interference from nitrogen source because the ruminal digestibility of the fibrous carbohydrates of this forage in diets are similar with different nitrogen sources. On the other hand, there were no metabolic problems at the levels of urea tested in this study because blood urea was not significantly increased, which explains similar performance of animals of all treatments. Evaluating the results of this study, we observed that sheep could receive diets with urea levels above $1 \%$ in the DM without having their performance compromised; in cases of high prices of soybean meal, the true protein could even be fully replaced by a NPN source like urea. Although some carcass characteristics were influenced by the substitution of soybean meal for urea, these alterations did not compromise the qualitative-quantitative aspects of these carcasses.

\section{Conclusions}

Substituting the nitrogen from soybean meal for nitrogen from urea provides similar performance in sheep consuming deferred buffelgrass hay.

\section{Acknowledgments}

The authors thank the Conselho Nacional de Desenvolvimento Científico e Tecnológico (CNPq) for financial support.

\section{References}

Alves, E. M.; Pedreira, M. S.; Pereira, M. L. A.; Almeida, P. J. P.; Gonsalves Neto, J. and Freire, L. D. R. 2012. Farelo da vagem de algaroba associado a níveis de ureia na alimentação de ovinos: balanço de nitrogênio, $\mathrm{N}$-ureico no plasma e parâmetros ruminais. Animal Sciences 34:287-295.

Alves, T. C.; Franzolin, R.; Rodrigues, P. H. M. and Alves, A. C. 2009. Efeitos de dietas com níveis crescentes de milho no metabolismo ruminal de energia e proteína em bubalinos. Revista Brasileira de Zootecnia 38:2001-2006.

Araújo Filho, J. T.; Amorim, P. L.; Monteiro, I. A.; Fregadolli, F. L. and Ribeiro, J. D. M. 2015. Características da carcaça de cordeiros submetidos à dietas com inclusão de levedura seca de cana-de-açúcar. Revista Brasileira de Saúde e Produção Animal $16: 337-349$

AOAC - Association of Official Analytical Chemists. 1990. Official methods of analysis. 15th ed. AOAC, Washington, DC.

Azevedo, H. O.; Barbosa, F. A.; Graça, D. S.; Paulino, P. V. R.; Souza, R. C.; Lavall, T. J. P. and Bicalho, F. L. 2015. Ureia de liberação lenta em substituição ao farelo desoja na terminação de bovinos confinados. Pesquisa Agropecuária Brasileira 50:1079-1086.

Azevedo, E. B.; Patiño, H. O.; Silveira, A. L. F.; Lopez, J.; Brüning, G. and Kozloskiii, G. V. 2008. Incorporação de uréia encapsulada 
em suplementos protéicos fornecidos para novilhos alimentados com feno de baixa qualidade. Ciência Rural 38:1381-1387.

Bezerra, S. B. L.; Véras, A. S. C.; Silva, D. K. A.; Ferreira, M. A.; Pereira, K. P.; Santos, G. R. A.; Magalhães, A. L. R. and Almeida, O. C. 2012. Morphometry and carcass characteristics of goats submitted to grazing in the Caatinga. Revista Brasileira de Zootecnia 41:131-137.

Berchielli, T. T.; Pires, A. V. and Oliveira, S. G. 2011. Nutrição de ruminantes. 2 ed. FUNEP, Jaboticabal.

Castagnara, D. D.; Neres, M. A.; Oliveira, P. S. R.; Meinerz, C. C. and Mesquita, E. E. 2012. Use of conditioning in the production of black and white oat hay using two cutting heights. Revista Brasileira de Zootecnia 41:1082-1092.

Cezar, M. F. and Sousa, W. H. 2007. Carcaças ovinas e caprinas: obtenção-avaliação-classificação. Editora Agropecuária Tropical, Uberaba.

Costa, M. R. G. F.; Pereira, E. S.; Silva, A. M. A; Paulino, P. V. R; Mizubuti, I. Y.; Pimentel, P. G.; Pinto, A. P. and Rocha Junior, J. N. 2013. Body composition and net energy and protein requirements of Morada Nova lambs. Small Ruminant Research 114:206-213.

Costa, V. A. C.; Detmann, E.; Valadares Filho, S. C.; Paulino, M. F.; Henriques, L. T. and Mantovani, H. C. 2009. Degradação in vitro da fibra em detergente neutro de forragem tropical de alta qualidade em função da suplementação com proteína e/ou carboidratos. Revista Brasileira de Zootecnia 38:1803-1811.

Chandrasekharaiah, M.; Thulasi, A. and Sampath, K. T. 2011. Microbial protein synthesis, nitrogen capture efficiency and nutrient utilisation in sheep fed on finger millet straw (Eleucine coracana)based diet with different rumen-degradable nitrogen levels. Journal of the Science of Food and Agriculture 91:1505-1510.

Detmann, E.; Queiroz, A. C.; Zorzi, K.; Mantovani, H. C.; Bayão, G. F. V. and Gomes, M. P. C. 2011. Degradação in vitro da fibra em detergente neutro de forragem tropical de baixa qualidade em função da suplementação com proteína verdadeira e/ou nitrogênio não-proteico. Revista Brasileira de Zootecnia 40:1272-1279.

Detmann, E.; Paulino, M. F.; Valadares Filho, S. C.; Batista, E. D. and Rufino, L. M. A. 2014. Aspectos nutricionais aplicados a bovinos em pastejo nos trópicos. p.239-267. In: Anais do Simpósio de Produção de Gado de Corte. DZO-UFV, Viçosa, MG, Brasil.

Dado, R. G. and Allen, M. S. 1995. Intake limitations, feeding behavior, and rumen function of cows challenged with rumen fill from dietary fiber or inert bulk. Journal of Dairy Science 78:118-133.

Freitas, P. M. D.; Santos, E. M.; Ramos, J. P. F.; Bezerra, H. F. C.; Silva, D. S.; Silva, I. F.; Perazzo, A. F. and Pereira, G. A. 2013. Efeito da adubação orgânica e altura de resíduo sobre a produção de fitomassa do capim-buffel. Revista Brasileira de Saúde e Produção Animal 14:587-598.

Gallo, S. B.; Merlin, F. A.; Macedo, C. M. and Reis, V. A. A. 2015. Duas fontes de proteína na dieta de cordeiros confinados. Revista Brasileira de Saúde e Produção Animal 16:317-324.

Garcia, C. A.; Monteiro, A. L. G.; Costa, C.; Neres, M. A. and Rosa, G. J. M. 2003. Medidas objetivas e composição tecidual da carcaça de cordeiros alimentados com diferentes níveis de energia em creep feeding. Revista Brasileira de Zootecnia 32:1380-1390.

Gonzaga Neto, S.; Silva Sobrinho, A. G.; Zeola, N. M. B. L. Marques, C. A. T. M.; Silva, A. M. A.; Pereira Filho, J. M. and Ferreira, A. C. D. 2006. Características quantitativas da carcaça de cordeiros deslanados Morada Nova em função da relação volumoso: concentrado na dieta. Revista Brasileira de Zootecnia 35:1487-1495.

González, F. H. D. and Silva, S. C. 2006. Introdução a bioquímica clínica veterinária. 2 ed. UFRGS, Porto Alegre.

Licitra, G.; Hernandez, T. M. and Van Soest, P. J. 1996. Standardization of procedures for nitrogen fractionation of ruminant feeds. Animal Feed Science and Technology 57:347-358.
Marques, C. A. T.; Medeiros, A. N.; Costa, R. G.; Carvalho, F. F. R.; Araújo, M. J. and Torreão, J. N. C. 2014. Performance and carcass traits of Moxotó growing goats supplemented on native pasture under semiarid conditions. Revista Brasileira de Zootecnia 43:151-159.

Mendes, C. Q.; Fernandes, R. H. R.; Susin, I.; Pires, A.V. and Gentil, R. S. 2010. Substituição parcial do farelo de soja por ureia ou amireia na alimentação de cabras em lactação. Revista Brasileira de Zootecnia 39:1818-1824.

Mendes, A. R.; Ezequiel, J. M. B.; Galati, R. L.; Nascimento, V. F.; Queiroz, M. A. A. and Pereira, E. M. O. 2006. Cinética digestiva e eficiência de síntese de proteína microbiana em novilhos alimentados com farelo de girassol e diferentes fontes energéticas. Revista Brasileira de Zootecnia 35:264-274.

Moraes, E. H. K.; Paulino, M. F.; Zervoudakis, J. T.; Detmann, E.; Valadares Filho, S. C. and Moraes, K. A. K. 2012. Aspectos produtivos e econômicos de novilhos mestiços alimentados com suplementos proteico-energéticos contendo ureia. Revista Brasileira de Zootecnia 41:1278-1284.

Moreira, J. N.; Lira, M. A.; Santos, M. V. F.; Araújo, G. G. L. and Silva, G. C. 2007. Potencial de produção de capim buffel na época seca no semi-árido pernambucano. Caatinga 20:20-27.

Mertens, D. R. 2002. Gravimetric determination of amylasetreated neutral detergent fiber in feeds with refluxing in beaker or crucibles: collaborative study. Journal of AOAC International $85: 1217-1240$

NRC - National Research Council. 1976. Nutrient requirements of sheep. National Academy Press, Washington, D.C.

NRC - National Research Council. 1985. Nutrient requirements of domestic animals: nutrient requirements of sheep. 6th ed. National Academy Press, Washington, D.C.

NRC - National Research Council. 2007. Nutrient requirements of small ruminants. National Academy Press, Washington, D.C.

Paixão, M. L.; Valadares Filho, S. C.; Leão, M. I.; Valadares, R. F. D.; Paulino, M. F.; Marcondes, M. I.; Fonseca, M. A.; Silva, P. A. and Pina, D. S. 2006. Uréia em dietas para bovinos: consumo, digestibilidade dos nutrientes, ganho de peso, características de carcaça e produção microbiana. Revista Brasileira de Zootecnia 35:2451-2460.

Rezende, L. H. G. S.; Albertini, T. Z.; Detmann, E.; Tomich, T. R.; Franco, G. L.; Lempp, B. and Morais, M. G. 2008. Consumo e digestibilidade do feno de capim-braquiária em bovinos de corte sob suplementação com mistura contendo sulfato de amônio, caseína e uréia. Revista Brasileira de Zootecnia 37:717-723.

Santos, G. R. A.; Guim, A.; Santos, M. V. F.; Ferreira, M. A.; Lira, M. A.; Dubeux Júnior, J. C. B. and Silva, M. J. 2005. Caracterização do pasto de capim-buffel diferido e da dieta de bovinos, durante o período seco no sertão de Pernambuco. Revista Brasileira de Zootecnia 34:454-463.

Silva, R. M.; Pereira Filho, J. M.; Silva, A. L. N.; Cezar, M. F.; Silva, A. M. A. and Oliveira, N. S. 2010. The effect of supplementation on the tissue composition of the commercial cuts of cross-bred F1 $($ Boer $\times$ SPRD) finished in native pasture. Revista Brasileira de Zootecnia 39:1353-1358.

Silva, D. J. and Queiroz, A. C. 2002. Analise de alimentos: métodos químicos e biológicos. 3 ed. Imprensa Universitária, Viçosa, MG, Brasil.

Valadares Filho, S. D. C. and Pina, D. S. 2011. Fermentação ruminal. 2 ed. Funep, Jaboticabal. p.565-591.

Voltolini, T. V.; Moraes, S. A.; Araújo, G. G. L.; Oliveira, P. L. T. and Pereira, L. G. R. 2010. Urea levels in multiple supplement for lambs grazing on buffelgrass. Acta Scientiarum. Animal Sciences 32:461-465.

Voltolini, T. V.; Moraes, S. A.; Araújo, G. G. L.; Pereira, L. G. R.; Santos, R. D. and Neves, A. L. A. 2011. Carcass traits and meat 
cuts of lambs receiving increasing levels of concentrate. Revista Ciência Agronômica 42:526-533.

Van Soest, P. J. 1994. Nutritional ecology of the ruminant. 2th ed. Cornell University Press, Ithaca.

Van Soest, P. J.; Robertson, J. B. and Lewis, B. A. 1991. Methods for dietary fiber, neutral detergent fiber, and nonstarch polysaccharides in relation to animal nutrition. Journal of Dairy Science 74:3583-3597.
Yáñez, E. A.; Resende, K. T.; Ferreira, A. C. D.; Pereira Filho, J. M.; Medeiros, A. N. and Teixeira, I. A. M. A. 2009. Relative development of tissues, commercial meat cuts and live weight components in Saanen goats. Revista Brasileira de Zootecnia 38:366-373.

Xenofonte, A. R. B.; Carvalho, F. F. R.; Batista, A. M. V. and Medeiros, G. R. 2009. Características de carcaça de ovinos em crescimento alimentados com rações contendo farelo de babaçu. Revista Brasileira de Zootecnia 38:392-398. 